\title{
Paloma Vidal e as mulheres mais ao sul, mais próximas de si mesmas
}

Mais ao sul.

VIDAL, Paloma.

Rio de Janeiro: Língua Geral, 2008. 128 p.

Escrever qualquer um consegue. Raros são aqueles que produzem literatura de qualidade. Isto é, conseguem dominar a linguagem, obtêm a contenção exata no desenvolvimento do enredo e, sobretudo, o poder de impacto de um golpe bem encaixado no queixo do leitor. Cortázar comparava a literatura com o boxe: no romance, o escritor vence por pontos; no conto, por nocaute.

Paloma Vidal (nascida em Buenos Aires, em 1975, e vivendo no Brasil desde os dois anos de idade) é uma dessas raras exceções. Os excelentes contos de $A$ duas mãos (Rio de Janeiro: 7Letras, 2003) mostraram um pouco do seu talento - confirmado agora com a publicação de Mais ao sul (Rio de Janeiro: Língua Geral, 2008).
Em $A$ duas mãos, livro que recebeu boas resenhas de Beatriz Resende e Flávio Carneiro, as personagens femininas estão em destaque, mulheres que tentam sobreviver em um mundo adverso, quase sempre controlado por homens ausentes, pouco preocupados em compreendê-las. Como reação a esse abandono afetivo, a esse distanciamento, surge um mecanismo compensatório: a construção de um cenário que nunca se tornará real, mas que ameniza o desamparo ("Contradança", "A ver navios", "A duas mãos").

Mais ao sul segue esse projeto, com vários acréscimos. Procurando retratar mulheres desenraizadas, habitantes de um mundo feérico e que, por inúmeros motivos, proclamam que a felicidade reside mais ao norte, Paloma Vidal, com coração pulsando mais ao sul, vai tecendo suas narrativas com tranquilidade, certa de que, no momento adequado, haverá de atingir o ponto exato, expor a fratura e a dor.

Na primeira parte do livro, o longo e dramático "Viagens" revela como esses temas estão à flor da pele, a sensação de que falta um chão para plantar raízes, as vidas estraçalhadas pelas complicações da política 
latino-americana: "Esse navio vai cruzar o Atlântico até Barcelona, onde nossa amiga vai morar, a milhares de quilômetros de distância de seu país, onde seu filho caçula foi seqüestrado e assassinado pelo regime militar". A narradora, que procura conter a ansiedade entre tantos escombros, se ocupa em relatar a recuperação de parte da história familiar que nunca compartilhou. Ao mesmo tempo, com as entranhas corroídas pela tristeza, sabe que, independentemente do que possa descobrir, é preciso sobreviver no exílio constante, procurando por um lugar onde possa se sentir em casa.

Os outros contos são mais curtos, poucas páginas. Os mais significativos são três. Em "A aula de tango", os vínculos não nomeados estabelecem, através do interdito, a sensação crescente de que é a falta que completa o destino dos personagens. "O retorno" relata/ reata a vontade de preencher esses vazios ("Deu um passo adiante erguendo a mala e equilibrouse na soleira da porta, num limiar entre dois mundos"), a luta sem quartel entre o desejado e o possível, o deslocamento entre os dois aeroportos construindo uma ponte entre o passado e o futuro. "Desassossego" é uma narrativa mais tensa, intensa, a história de uma mulher que põe "a mesa para o seu fantasma", aceitando o embate contra as forças que a ameaçam e, ao mesmo tempo, a acariciam: "Andou por várias horas, sem vontade de se proteger, e só voltou para casa quando seus pés o exigiram. Naquela noite, esperaria seu fantasma como se espera um convidado, uma visita desejada".
Embalada pela nostalgia das delícias que deixou de provar, abre as portas da casa e derruba as fronteiras demarcadas pelo proibido.

Os contos de Mais ao sul, histórias repletas de aflição, relatos de mulheres que, de uma forma ou de outra, aguardam pelo tempo de partir ou de encontrar a si mesmas, constituem um daqueles momentos literários em que a voz feminina se pronuncia com clareza, sem reter sentimentos, sem fazer concessões. Ao mesmo tempo, como que a lembrar as duas faces da mesma moeda, em alguns momentos Paloma Vidal reatualiza 0 mito de Cassandra, vidente condenada a prever um futuro em que ninguém acredita.

Por último, cabe destacar uma característica da prosa de Paloma Vidal: a publicação de várias versões de seus contos, muitas vezes suprindo parágrafos, alterando pequenos detalhes, lapidando o texto. Exemplos desse "work-in-progress" são "Desassossego" que, ligeiramente modificado, foi publicado com outro título ("A espectadora") na antologia $A$ visita (São Paulo: Barracuda, 2005); "Viagens", que sofreu grandes mudanças depois de publicado inicialmente em Paralelo - 17 contos da nova literatura brasileira (Rio de Janeiro: Agir, 2004); "Mundos paralelos", publicado em 25 mulheres que estão fazendo a nova literatura brasileira (Rio de Janeiro: Record, 2004), que se transformou em "O retorno".

Raul J. M. Arruda Filho Universidade Federal de Santa Catarina 